\title{
MITÄ KAIKKEA PUHEELLA VOIDAANKAAN TEHDÄ?
}

John L. Austin 2016. Näin tehdään sanoilla (englanninkielisestä alkuteoksesta How to Do Things with Words 1962/1975 suomentanut Risto Koskensilta). Tampere: niin \& näin. 186 s. ISBN 978-952-7189-05.4

Brittiläinen kielifilosofi John Langshaw Austin (1911-1960) piti Harvardin yliopistossa vuonna 1955 luentosarjan How to Do Things with Words. Näiden niin sanottujen William James -luentojen sisältö ilmestyi James O. Urmsonin ja Marina Sbisán toimittamassa painetussa muodossa ensi kerran vuonna 1962 ja tämän jälkeen vuonna 1975. Vastikään ilmestynyt Näin tehdään sanoilla (niin \& näin, 2016) on Risto Koskensillan suomennos tästä klassikkoteoksesta. Austinin luentojen lisäksi suomenkielinen laitos sisältää englanninkielisten laitosten esipuheiden suomennokset sekä suomentajan alku- ja jälkisanat.

Klassikkoteoksessaan Austin kritisoi erityisesti "loogiseksi positivismiksi" kutsuttua filosofian koulukuntaa, jonka mukaan ihanteellisimmillaan kieltä käytetään vain sellaisten väitteiden esittämiseen, jotka voidaan joko todentaa tai kumota empiiristen havaintojen pohjalta. Austin huomautti, ettei suuressa osassa ihmisten luonnollista kielenkäyttöä ollut tästä näkökulmasta mitään järkeä. Kuitenkin, kuten Austin teoksessaan osoitti, kieltä ei käytetä vain väittämiseen, vaan sen avulla tehdään asioita. Tämän ajatuksen oli jo aiemmin nostanut esiin itävaltalais-englantilainen filosofi Ludwig Wittgenstein (1889-1951), mutta vasta Austin alkoi toden teolla pohtia sitä, kuinka kielellä tekemistä voitaisiin tutkia järjestelmällisesti. Austinin työ loi pohjan niin sanotun puhetekoteorian synnylle.

\section{SANOILLA TEKEMINEN - ERITYISTAPAUS VAI NORMAALI TILANNE?}

Klassikkoteoksensa ensimmäisessä luennossa Austin erottaa asioiden toteamisen kielen avulla tekemisestä. Toteamukset, joita Austin nimitti konstatiiveiksi, voivat olla tosia tai epätosia. Sen sijaan lausumia, joiden avulla tehdään asioita, kuten kastetaan lapsi, vihitään avioliittoon tai lyödään vetoa, ja joita Austin kutsui performatiiveiksi, ei ole mielekästä arvioida niiden totuudellisuuden näkökulmasta. Sen sijaan performatiivilausumia voidaan arvioida niiden onnistuneisuuden näkökulmasta. Senkään jälkeen, kun performatiivilausuma on epäonnistunut (esim. ”Julistan teidät aviopuolisoiksi", kun puhujalla ei ole virallista avioliittoonvihkimisoikeutta), sitä ei pidetä valheellisena, vaan mitättömänä.

Seuraavalla luennollaan ja siitä eteenpäin Austin tarkastelee performatiivien luonnetta. Lisäksi hän pohtii tarkemmin niitä kriteerejä, jotka erottavat konstatiivi- ja performatiivilausumat toisistaan, todeten, ettei toimivaa kriteeristöä itseasiassa edes löydy. Useissa performatiivilausumissa on myös konstatiivinen ulottuvuus. Esimerkiksi varoitusta "Niityllä on härkä" voidaan vallan hyvin arvioida myös sen sisältämän kuvauksen paikkansapitävyyden näkökulmasta. Toisaalta useissa konstatiivilausumissa on mukana myös performatiivinen ulottuvuus. Esimerkiksi toteamus "Johnin lapset ovat kaljuja" ei ole tosi eikä epätosi, jos Johnilla ei ole lainkaan lapsia. Sen sijaan tällainen toteamus on mitätön.

Luentosarjansa puolivälin tienoilla Austin lähtee liikkeelle ikään kuin uudelleen alusta. 
Hän hylkää ajatuksen konstatiivien ja performatiivien välisestä vastakkainasettelusta ja sen sijaan toteaa, että minkä tahansa asian sanominen on aina jonkin asian tekemistä; myös toteamalla tehdään asioita aivan kuten julistamalla, käskemällä tai anteeksi pyytämällä. Tämän oivalluksen jälkeen Austin esittelee uuden korvaavan käsitteellisen viitekehyksen, jonka keskiössä on "kokonainen puheteko kokonaisessa puhetilanteessa" (s. 132).

Austinin mukaan jokainen lausuma on teko kolmella eri tavalla: lokutionaarisena, illokutionaarisena ja perlokutionaarisena tekona. Lausuman lokutionaarinen puoli viittaa puheen aistittavissa olevaan puoleen: äänteiden foneettiseen toteutumiseen, sanojen järjestymiseen jonkin kielijärjestelmän puitteissa ymmärrettäviksi kokonaisuuksiksi sekä siihen, kuinka näillä sanoilla kussakin tilanteissa viitataan maailmaan. Kuitenkin, kuten edellisestä on jo käynyt ilmi, Austinin päähuomio ei kohdistunut siihen, mitä puhuttaessa kapeasti ottaen sanotaan, vaan siihen, mitä näillä sanoilla kulloinkin tehdään. Tätä asiaa kuvaa lausuman illokutionaarinen puoli. Kuten Austin toteaa, "on suurestikin merkitystä, neuvommeko vai pelkästään ehdotamme, vaiko itse asiassa määräämme, annammeko lujan lupauksen vai ilmoitammeko vain epämääräisen aikomuksen tai muuta sellaista” (s. 93). Kuitenkaan sen selvittämiseen, mikä illokutionaarinen teko on milloinkin kyseessä, ei riitä pelkkä sanojen tarkastelu. Esimerkiksi pelkkä imperatiivi "Mene" voi olla, käsky, neuvo tai sen anelemista, että toinen menisi. Samoin lausuma "Niityllä on härkä" voi olla varoitus, mutta se voi olla myös harmiton ympäristön kuvaus. Niinpä Austin korostaakin, ettei lausuman illokutionaarista puolta ole mahdollista ymmärtää ilman koko puhetilanteen ja sen kaikkien taustatekijöiden huomioon ottamista. Lopuksi Austin erottaa lausumasta myös sen perlukotionaarisen puolen, jolla Austin viittaa puheteon kausaalis- luonteisiin vaikutuksiin - siihen, mitä teolla saadaan aikaan. Esimerkiksi varoitus "Niityllä on härkä" saa onnistuessaan aikaan sen, että kuulija lisää valppauttaan.

Viimeisessä luennossaan Austin esittää alustavan luokittelun erilaisista lausumien avulla tehtävistä illokutionaarisista teoista. Tässä tehtävässään hän turvautuu luetteloon sellaisista englannin kielen verbeistä, joissa puhujan on mahdollista ja mielekästä käyttää aktiivin indikatiivin preesensin yksikön ensimmäistä persoonamuotoa. Austinin luokittelussa tällaiset verbit edustavat viittä eri tyyppiä: Verdiktiivit, kuten "totean", "tulkitsen", "määritän", "päättelen" ja "arvelen", liittyvät jotakin asiaa koskevan, harkintaa edellyttävän, lausunnon antamiseen. Ekserkitiivit, kuten "nimitän", "vapautan", "kastan", "määrään" ja "erotan", ovat oikeuksien ja vaikutusvallan käyttämistä. Komissiivit, kuten "lupaan", "aion", "takaan", "annan luvan" ja "lyön vetoa", velvoittavat tai sitouttavat puhujan johonkin. Behabitiivit, kuten "pyydän anteeksi", "kiitän", "olen pahoillani", "onnittelen" ja "toivotan tervetulleeksi", liittyvät asenteisiin ja sosiaaliseen käyttäytymiseen. Ekspositivit, kuten "huomautan", "kerron", "selitän", "oikaisen" ja "perun sanomani", taas ilmaisevat metatasolla, kuinka lausuma suhteutuu käytävään keskusteluun. Austin ei väittänyt taksonomiaansa valmiiksi, vaan hän piti sitä ainoastaan alustavana yrityksenä päästä puhetekojen tutkimuksessa eteenpäin.

\section{PUHETEOT JA PUHUJIEN TAVOITTEET}

Käsillä olevaa Austinin klassikkoteosta, kuten sen pohjalta syntynyttä puhetekoteoriaa laajemminkin, on arvosteltu laajalti. Yksi kritiikin aihe on ollut Austinin puhujakeskeinen lähestymistapa vuorovaikutuksessa tapahtuvaan kielenkäyttöön. Vaikkei puhetekoteoriassa oleteta, että sanojen ja asioiden 
välillä olisi vastaavuussuhdetta, kuitenkin sanojen ja tekojen välillä ajatellaan jonkinlaista vastaavuutta olevan. Puheteon toteutumista määrittää puhujan intentionaalinen eli tavoitteellinen toiminta, jolloin puheteko on se keino, jonka avulla puhuja pyrkii saamaan kuulijassa aikaan tietyn vaikutuksen. Puhetekoteoriaa arvostelleet tutkijat näkevät vuorovaikutuksen kuitenkin ennen kaikkea osallistujien yhteisenä toimintana, jolloin yksittäisen puheteon merkitystä ei voi pelkistää niihin tavoitteisiin, joita puhujalla kuulijaan nähden on (Hakulinen, 1989). Yksittäisten puhetekojen tavoitteellisuudesta puhumista hankaloittaa myös keskustelujen prosessimainen luonne - se, että yhtä puhetekoa, esimerkiksi pyyntöä, saatetaan valmistella jo kauan ennen varsinaisen pyyntövuoron esittämistä (Levinson, 2013, s. 119-122). Lisäksi lausumalla voi olla useita käyttötarkoituksia eri tulkitsijoiden mukaan, vaikka puhuja olisi yksi ja sama henkilö.

Toisaalta kukaan ei voi kiistää, etteikö vuorovaikutuksessa tapahtuvaan kielenkäyttöön liittyisi aina myös puhujien mielensisäisiä prosesseja. Vuorovaikutuksen kognitiivinen perusta onkin kiinnostava tutkimusaihe, koska on perusteltua ajatella, että ihmisen kognitiiviset kyvyt ovat muovautuneet vastaamaan nimenomaan sosiaalisen vuorovaikutuksen tarpeita (Levinson, 1995, 2006; ks. myös Scott-Phillips, 2014). Austinin ajatukset puhujien toiminnan tavoitteellisuudesta ja kaikista niistä ongelmista, joita tällaisten tavoitteiden toteutumisen esteeksi voi tulla, soveltuvat hyvin kognition ja vuorovaikutustapahtumien välisen suhteen käsitteellistämiseen. Austinin analyysi erityyppisistä puhetekojen kompastumista on rikas ja monivivahteinen, ja hänen esittelemänsä teoreettiset työkalut saattavat hyvinkin olla hyödyksi esimerkiksi erilaisista kommunikaatiovaikeuksista kärsivien henkilöiden vuorovaikutusta koskevissa tutkimuksissa.

\section{OMINTAKEINEN TUTKIMUSAINEISTO}

Teoksensa alkupuolella Austin esittää ajatuksen, että puhetekojen järjestelmällisen tutkimuksen eteenpäin viemiseksi tarvitaan luettelo kaikista englannin kielen "läpinäkyvistä performatiiviverbeistä” (s. 67). Kirjansa lopussa hän täsmentää, että se, mitä itseasiassa tarvitaan, on luettelo lausumien "illokutionaarisista voimista" (s. 133) eli kaikista lausumien avulla mahdollisesti tehtävistä puheteoista. Kuten Austin kirjansa lopussa havainnollistaa, tässä on kyse tietynlaisten, tekemistä kuvaavien, englannin kielen verbien kartoittamisesta, joiden erityisyys on Austinin mukaan siinä, että ne kertovat suoraan siitä, mistä puheteosta milloinkin on kyse. Niinpä esimerkiksi lausuma "Lupaan, että siivoan huomenna", on puhetekona lupaus.

Performatiivisten verbien yhteys puhetekoihin on herättänyt ankaraa arvostelua luonnollisia, video- tai äänitallennettuja, vuorovaikutustilanteita analysoineiden vuorovaikutustutkijoiden piirissä. On esimerkiksi esitetty, etteivät puhetekoverbien edustamat puhetekojen luokitukset (ts. metalingvistiset kategoriat) olisi merkityksellisiä puhujille vielä siinä vaiheessa, kun nämä suunnittelevat ja toteuttavat puhetekonsa. Sen sijaan tällaiset luokitukset muuttuvat oleellisiksi vasta sitten, kun vuorovaikutuksen osallistujat vaativat toinen toisiltaan heidän aikaisempia puhetekojaan koskevia selontekoja (Heritage 1990/1991; Drew 1995; Hopper 2005). Tällaisia tilanteita on esimerkiksi silloin, jos yksi vuorovaikutuksen osallistuja on rikkonut tilanteessa vallinneita normatiivisia odotuksia, esimerkiksi jättänyt vastaamatta tervehdykseen ("Etkö ole oppinut että tervehdykseen kuuluu vastata?"). Toisaalta vuorovaikutuksen osallistujat saattavat nimetä toimintonsa tietynlaista toimintakategoriaa 
käyttäen jo etukäteen - viestiäkseen, että he sitoutuvat olemaan selontekovelvollisia vain ja ainoastaan tämän toiminnon osalta (esim. "Se, mitä kohta esitän, on vain ehdotus, jota voi vielä hyvin muuttaa"). Niinpä metalingvistiset puhetoimintojen kategoriat saattavat välillä olla jopa harhaanjohtavia sen suhteen, mitä puhujat itse asiassa tekevät (esim. "Lupaan, että joudut vaikeuksiin"). Lisäksi on esitetty, ettei mielekäs vuorovaikutus ja keskustelu oikeastaan edes edellytä metalingvististä puhetekojen kategorisoimista, vaan että jo pelkästään vuorojen sisältämien rakenneosien pohjalta puhujat kykenevät vastaamaan toistensa puheenvuoroihin ainakin sinne päin (Sidnell \& Enfield, 2014).

Vaikkei Austinin empiirinen lähestymistapa siis kestä kovin tiukkaa tarkastelua, sitä on kuitenkin tietyssä mielessä syytä myös puolustaa. Ottaen huomioon, että Austin oli filosofi, hän oli erittäin kiinnostunut empiriasta. Hän halusi luoda aiempaa vankemman pohjan filosofialle ja yksittäisten filosofien intuitioiden sijaan rakentaa ajattelunsa varmemman "tutkimusaineiston" varaan (s. 158). Austin teki asian suhteen voitavansa: hän uskoi, että tarvittavan vakaan pohjan tutkimukselle tarjoaisi kielenkäyttö kaikkine vivahteineen, sen sanavaraston kattaessa "kaikki ne erottelut ja yhteydet, jotka ihmiset ovat lukuisien sukupolvien aikana katsoneet tarpeellisiksi ja muodostamisen arvoisiksi” (s. 159). Tällainen näkemys on jo sinänsä huomionarvoinen. Kysymys siitä, millaisia metalingvistisiä puhetekokategorioita eri kielet ja kulttuurit tarjoavat puhujien kielenkäytön vivahteiden jäsentämiseen, on viime aikoina noussut myös monen vuorovaikutustutkijan mielenkiinnon kohteeksi (ks. esim. Sidnell \& Enfield, 2012).

\section{KUINKA TEOS "TEKEE SANOILLA"}

Austinin teosta on moitittu vaikeatajuiseksi. Yksi syy tähän lienee se, että teoksessa on kyse luentosarjasta, eikä sitä näin ollen ole alun perin laadittu luettavaksi. Lukijan kannattaakin käyttää kirjaa lukiessaan apuna mielikuvitustaan ja esimerkiksi jokaisen luvun alussa kuvitella itsensä opiskelijaksi, joka tulee luennolle ilman minkäänlaista muistikuvaa siitä, mistä edellisellä luennolla on puhuttu. Näin on helpompi sietää lukujen alussa olevia pitkällisiä, edellisissä luvuissa esitettyjen asioiden kertaamisia. Lukijan kannattaa myös yrittää mielessään kuulla teksti ikään kuin luennoitsijan suusta. Tällöin hyvän mielikuvituksen omaava lukija saattaa tärkeiden asioiden kohdalla kuulla luennoitsijan korottavan ääntään ja sivuasioihin kohdistuvien huomautusten kohdalla kuvitella puheen nopeatempoiseksi hiljaiseksi muminaksi. Teosta tutkiessaan lukija joutuu siis näkemään hieman ylimääräistä vaivaa erottaakseen oleellisen epäoleellisesta ja jäsentääkseen teoksen suuret linjat.

Toinen syy kokemukseen Austinin teoksen vaikeatajuisuudesta liittyy kirjoittajan argumentoinnin sisältämiin loppumattoman pedanttisiin pohdintoihin, joiden kohdalla lukijan mielenkiinto helposti herpaantuu. Kirjansa lopussa myös Austin itse toteaa tämän nimenomaisen ongelman olemassaolon: hän myöntää esityksensä pitkäveteisyyden ja kuivakkuuden, mutta lisää tähän, että vaikka näin on, hänen lähestymistapansa ei kuitenkaan ole tehnyt hänen esityksestään "läheskään niin pitkäveteistä kuin asian läpi ajattelemisesta ja kirjoittamisesta” (s. 146). Tällainen itseironia auttaa kyllä lukijaa antamaan Austinille hänen pedanttisuutensa anteeksi.

Kirjan suomentanut Risto Koskensilta on tehnyt valtavan työn saattaessaan Austinin klassikkoteoksen asiasisältöjä ja vivahteita suomenkieliselle lukijalle ymmärrettävään 
muotoon. Hauskoina suomennoksen yksityiskohtina mainittakoon vaikkapa lausuma, jonka mukaan "viukkaat puhvenet päinillä harpitellen kieruloivat" (s. 91), tai toteamus, että"sanoessani: 'Minä hain sen', päästin äänet 'Minä haisen'” (s. 111). Austinin tapa leikitellä sanonnoilla on epäilemättä tuottanut suomentajalle päänvaivaa, mutta työn lopputulokset ovat ajoittain suoranaisia helmiä. Tiesittekö esimerkiksi sen, että "kissaa voi rääkätä muillakin konsteilla kuin pyyhkimällä sillä pöytää” (s. 51)?

Alkusanoissaan suomentaja perustelee käännösratkaisujaan, joista suurimman osan hyväksyminen onnistui allekirjoittaneelta heti. Mielestäni esimerkiksi teoksen keskeisten sanojen convention ja conventional kääntäminen ilmaisuilla "tapaan perustuva" ja "tapaperustainen" oli erittäin toimiva ratkaisu. Vaikeammin sulatettavaksi sen sijaan koin käännösratkaisun koskien sanoja happy ja unhappy, joilla Austin omintakeisesti viittaa puhetekojen onnistuneisuuteen - tai "luontumiseen", kuten Koskensilta on käsitteet suomentanut. Vaikka "luontua"-verbi näyttää toimivan suomenkielisessä tekstissä varsin sujuvasti, kuitenkaan se ei mielestäni tee täyttä oikeutta Austinin ajatuksille - erityisesti niille, jotka koskevat puhetekojen kariutumista. Austinin kuvauksessa puheteot tulevat kariutuessaan mitätöidyiksi, kumotuiksi tai vesitetyiksi, mutta ajatus puhetekojen "luontumattomuudesta" herättää lähinnä mielleyhtymän väkinäisistä tilanteista, joissa puhujat eivät ole toiminnassaan omalla mukavuusalueellaan. Puheteon kankeus tai luistamattomuus on kuitenkin aika lailla eri asia kuin puheteon nollautuminen, tyhjäksi tuleminen, jollaisena Austin puhetekojen kariutumista pääsääntöisesti kuvaa. Niinpä "luontua"-verbin sijasta olisin mieluusti nähnyt happy-sanan suomennosratkaisujen pohjana Austinin ajatuksiin mielestäni hyvin sopivan, helposti ymmärrettävän, verbin ”onnistua”.
Suomentajan jälkisanat, joissa kerrotaan Austinin ajattelijahahmosta ja filosofisesta menetelmästä sekä hänen tekstiensä tulkitsemisesta, kuuluvat kirjan parhaaseen antiin: Koskensillan teksti on erinomaisen valaiseva ja epäilemättä auttaa Austiniin aiemmin perehtymätöntäkin lukijaa saamaan kirjan ideasta kiinni.

\section{Melisa Stevanovic}

VTT, tutkijatohtori

Helsingin yliopisto, sosiaalitieteiden laitos

Intersubjektiivisuus vuorovaikutuksessa

-huippuyksikkö

melisa.stevanovic@helsinki.fi

\section{LÄHTEET}

Drew, P. (1995). Interaction sequences and anticipatory interactive planning. Teoksessa E. Goody (toim.), Social Intelligence and Interaction (s. 111-138). Cambridge: Cambridge University Press.

Hakulinen, A. (1989). Keskustelun luonnehtimisesta konteksti- ja funktionaalisten tekijöiden nojalla. Teoksessa A. Hakulinen (toim.), Suomalaisen keskustelun keinoja I (s. 41-72). Kieli 4. Helsingin yliopiston suomen kielen laitos.

Heritage, J. (1990/1991). Intention, meaning and strategy: Observations on constraints from conversation analysis. Research on Language and Social Interaction, 24, 311-332.

Hopper, R. (2005). A cognitive agnostic in conversation analysis: When do strategies affect spoken interaction? Teoksessa H. te Molder \& J. Potter (toim.), Conversation and Cognition (s. 134-158). Cambridge: Cambridge University Press.

Koskensilta, R. (2016). Suomentajan jälkisanat. Teoksessa J. L. Austin. Näin tehdään sanoilla (s. 151-164), suomentanut Risto Koskensilta. Tampere: niin \& näin.

Levinson, S. C. (1995) Interactional biases in human thinking. Teoksessa E. Goody (toim.), Social Intelligence and Interaction (s. 221-260). Cambridge: Cambridge University Press. 
Levinson, S. C. (2006). On the human "interaction engine”. Teoksessa N. J. Enfield \& S. C. Levinson (toim.), Roots of Human Sociality (s. 39-69). Oxford: Berg.

Levinson, S. C. (2013). Action formation and ascription. Teoksessa J. Sidnell \& T. Stivers (toim.), Handbook of Conversation Analysis (s. 103-130). Boston, MA: Wiley-Blackwell.

Scott-Phillips, T. (2014). Speaking our minds: Why human communication is different, and how language evolved to make it special. Basingstoke: Palgrave Macmillan.
Sidnell, J. \& Enfield, N. J. (2012). Language diversity and social action: A third locus of linguistic relativity. Current Anthropology, 53, 302-333.

Sidnell, J. \& Enfield, N. J. (2014). The ontology of action, in interaction. Teoksessa N. J. Enfield, P. Kockelman, \& J. Sidnell (toim.), The Cambridge Handbook of Linguistic Anthropology (s. 423446). Cambridge: Cambridge University Press. 